Article

\title{
Exploring the Antioxidant Effects and Periodic Regulation of Cancer Cells by Polyphenols Produced by the Fermentation of Grape Skin by Lactobacillus plantarum KFY02
}

\author{
Jia Liu ${ }^{1,2,3}$, Fang Tan ${ }^{4, *}$, Xinhong Liu ${ }^{1,2,3,5}$, Ruokun Yi ${ }^{1,2,3}$ and Xin Zhao 1,2,3,*(D) \\ 1 Chongqing Collaborative Innovation Center for Functional Food, Chongqing University of Education, \\ Chongqing 400067, China; liujia@cque.edu.cn (J.L.); liuxh@cque.edu.cn (X.L.); yirk@cque.edu.cn (R.Y.) \\ 2 Chongqing Engineering Research Center of Functional Food, Chongqing University of Education, \\ Chongqing 400067, China \\ 3 Chongqing Engineering Laboratory for Research and Development of Functional Food, \\ Chongqing University of Education, Chongqing 400067, China \\ 4 Department of Public Health, Our Lady of Fatima University, Valenzuela 838, Philippines \\ 5 College of Biological and Chemical Engineering, Chongqing University of Education, \\ Chongqing 400067, China \\ * Correspondence: tanfang@foods.ac.cn (F.T.); zhaoxin@cque.edu.cn (X.Z.); Tel.: +86-23-62653650 (X.Z.)
}

Received: 15 September 2019; Accepted: 4 October 2019; Published: 6 October 2019

\begin{abstract}
Lactobacillus plantarum KFY02 (LP-KFY02) was isolated from naturally fermented yoghurt in Xinjiang. We previously demonstrated that LP-KFY02 has good biological activity in vitro. In this study, LP-KFY02 was used to ferment grape skin, and the LP-KFY02 fermented grape skin extract solution (KFSE) was examined for its antioxidant ability in a human embryonic kidney (293T) cell oxidative damage model caused by $\mathrm{H}_{2} \mathrm{O}_{2}$ and its inhibitory effect on human hepatoma (HepG2) cells. The results showed that KFSE reduced the degree of oxidative damage in 293T cells, increased the relevant expression levels of superoxide dismutase (SOD), catalase (CAT), glutathione (GSH), and GSH-peroxidase (GSH-Px), and total antioxidant capacity (T-AOC), and decreased the expression levels of lactate dehydrogenase (LDH), malondialdehyde (MDA), and nitric oxide (NO). The expression of genes and proteins of SOD, CAT, GSH, and GSH-Px was up-regulated. In addition, KFSE-induced growth inhibition appeared to be through induction of cell-cycle arrest. This induction was accompanied by a reduction in the expression of cell-cycle genes, such as cyclin-D1 and CDK4. In addition, KFSE induced gene expression of $p 21$, the apoptosis gene wild-type $p 53$ and the caspase family. At the protein expression level, Bax and Caspase-8 were up-regulated, and the inflammatory marker Nuclear Factor Kappa-B (NF-kB) was down-regulated. The fermentation solution polyphenols were separated and identified as epicatechin gallate, coumarin, new chlorogenic acid, rutin, resveratrol, chlorogenic acid, rosmarinic acid, etc. by HPLC. Overall, these results demonstrate that KFSE significantly attenuated oxidative damage in 293T cells and inhibited tumor growth in HepG2 cancer cells, induces cell-cycle arrest and affects proteins involved in cell-cycle regulation and proliferation. This suggests that KFSE may also be explored as a neo-adjuvant to expansion of hepatoma.
\end{abstract}

Keywords: Lactobacillus plantarum KFY02; polyphenols; HepG2; antioxidative; apoptotic

\section{Introduction}

Epidemiological studies have shown that the incidence of hepatoma is increasing year by year due to environmental factors and lifestyle habits. The liver is an important organ of the human body. 
It mainly functions in detoxification. Many people are already in advanced stages when they are diagnosed with hepatoma. The symptoms of hepatoma are not obvious at an early stage. Patients can have no symptoms even after a long period of illness. When the disease develops to a certain extent, it will gradually produce pain in the liver area, loss of appetite, fatigue, weakness, and other symptoms. Ascites, hematemesis, coma, and other symptoms may occur in the advanced stage. The main treatment for hepatoma is surgical resection combined with comprehensive drug therapy or API-specific biological immunotherapy. The prevention of hepatoma should start with the cause. The preventive measures for hepatoma include abstaining from alcohol, reducing the pollution of pesticides, and supplementing trace elements such as selenium; selenium can induce differentiation and inhibit proliferation. In daily life, one can also eat certain liver-protecting foods, such as mushrooms and cabbages. In addition, clinical trials in patients with phenolic phytochemicals have shown that these drugs have potential chemo-preventative properties and low toxicity [1-3]. Since the symptoms of hepatoma are not significant, most patients are in the middle and late stages when they are diagnosed. Due to the abundant blood supply to the liver, cancer cells are easily transferred into and out of the organ, resulting in difficult treatment conditions. In a previous study, resveratrol was effective in inhibiting the growth of hepatoma [4]. Functional foods, such as kiwi, strawberry, and green tea, are rich in polyphenols and have been shown to be effective against cancer [5-7]. Polyphenols are known to have anti-proliferative and antioxidative effects on hepatoma cells.

Polyphenols are compounds found in plant foods that have potential health-promoting effects. These compounds are found in some common plant-based foods, such as tea, soy, red wine, vegetables, and fruits. Oxidative damage is an important cause of many chronic diseases, such as cardiovascular disease, cancer, and ageing. The antioxidant function of polyphenols can prevent these chronic diseases. In addition to the antioxidant effects of polyphenols, researchers have found that taking polyphenols while eating high-fat foods can reduce the health risks of high-fat foods. Grape contains components that are similar to those found in green tea, including polyphenol constituents such as resveratrol, gallic acid, catechin, quercetin, kaempferol, and several anthocyanins [8,9]. Studies have shown that polyphenols have antioxidant, anti-aging, and radiation-resistant properties [10]. For example, edible polyphenols enter the body, undergo a reduction reaction and are metabolized by the liver to the blood or other tissues to achieve a functional effect [11]. Our previous study also showed that the polyphenols in green tea inhibited hepatoma cell growth, induced apoptosis, and decreased the expression of genes that control apoptosis and the cell cycle in hepatoma (HepG2) cells.

Probiotics are a class of active microorganisms that can be beneficial to the host by altering the composition of the flora at a certain part of the host [12]. Probiotics and their metabolites have very high value, including promoting the digestion and absorption of nutrients, improving the body's immunity, maintaining the balance of intestinal flora structure, improving meat quality, improving the body's antioxidant level, inhibiting intestinal inflammation, and protecting intestinal mucosal barriers $[13,14]$. People with low immunity and weak bowel function have a good therapeutic response to probiotics. Furthermore, probiotics are also suitable for cancer patients who accepted chemotherapy or radiation therapy, because microbes in patients are easily killed by chemotherapy drugs, resulting in an imbalance of intestinal flora, so chemotherapy or radiotherapy should be actively supplemented with probiotics [15]. In patients with cirrhosis and periarthritis, probiotics can inhibit the production of fungi in the intestine, reduce endotoxin levels in the blood, reduce intestinal acidity, and prevent intestinal endotoxemia [16]. Our research used the Lactobacillus plantarum KFY02 (LP-KFY02, China General Microbiological Culture Collection Center, CGMCC No: 15638), which was isolated from the naturally fermented yoghurt in Korla, Xinjiang, by the Chongqing Collaborative Innovation Center for Functional Food. Early functional activity studies indicate that the strain have good resistance to gastric acid and bile salt activity. Moreover, the strain has a significant effect on the regulation of lipid metabolism in mice.

$293 \mathrm{~T}$ is a kind of cell line that is easy to transfect and construct model. Many oxidative stress model studies have selected 293T cells as sample models, and all had achieved good results [17]. 
Therefore, we selected 293T cells to establish an oxidative damage model caused by $\mathrm{H}_{2} \mathrm{O}_{2}$ and explore the effect of the solution fermented from grape skin by Lactobacillus plantarum KFY02 on the oxidative damage model. Moreover, HepG2 is a kind of liver cancer cell line with a short growth cycle and stable expression, which has made great contributions to the research of liver cancer diseases. In this study, we showed that the solution fermented from grape skin by Lactobacillus plantarum KFY02 can effectively alleviate the oxidative damage of 293T cells caused by $\mathrm{H}_{2} \mathrm{O}_{2}$ and significantly inhibits the growth and migration of HepG2 cells, primarily through the induction of cell-cycle arrest. These data, therefore, suggest that the solution fermented from grape skin by Lactobacillus plantarum KFY02 warrants further investigation as a treatment for therapy-resistant hepatoma.

\section{Materials and Methods}

\subsection{Fermentation}

Fresh grape skin was chilled in a vacuum and then pulverized into a powder. The grape skin powder was dissolved in sterile water at 1:10 (g:V) and inoculated with $1 \times 10^{7} \mathrm{CFU} / \mathrm{mL}$ Lactobacillus plantarum KFY02 and the Lactobacillus delbrueckii subsp. bulgaricus (LB, China General Microbiological Culture Collection Center, CGMCC No. 1.16075) at 10\% (V:V), respectively. Then, the mixture was fermented at $37^{\circ} \mathrm{C}$, at $100 \mathrm{rpm}$ on a constant temperature shaker for $24,48,72,96$, and $120 \mathrm{~h}$, and centrifuged at $12,000 \mathrm{rpm}$ for $10 \mathrm{~min}$. The supernatant was taken and stored at $-80^{\circ} \mathrm{C}$ (KFSE: The fermentation solution fermented by Lactobacillus plantarum (LP)-KFY02; BFSE: The fermentation solution fermented by Lactobacillus delbrueckii subsp. bulgaricus). In the control group, $10 \mathrm{~g}$ of grape skin powder was dissolved in $100 \mathrm{~mL}$ of $60 \%$ ethanol solution, and a water bath was used at $70{ }^{\circ} \mathrm{C}$ for $4 \mathrm{~h}$. The precipitate was discarded and then evaporated to remove the ethanol and obtain grape skin extract (WS: The solution extracted by ethanol).

\subsection{In Vitro Antioxidant Analysis}

Previously described methods by Thaipong [18] and Roberta [19] were used to prepare 1,1-diphenyl-2-picrylhydrazyl (DPPH) radical-scavenging assay (Solarbio Life Sciences, Beijing, China) and 2,2' -azino-bis(3-ethylbenzothiazoline-6-sulfonic acid) (ABTS; Solarbio Life Sciences, Beijing, China) working fluid; the absorbance was measured using a multi-function micro-plate reader (Thermo Fisher Scientific, New York, NY, USA), and the ability of the fermentation solution to scavenge free radicals was calculated.

\subsection{Culture of Cell}

Human hepatoma (HepG2) cells and human embryonic kidney (293T) cells were purchased from the Cell Bank of the Chinese Academy of Sciences (Shanghai, China). The cell lines were cultured using DMEM supplemented with 10\% fetal bovine serum (FBS; Sijiqing, Hangzhou Sijiqing Biological Engineering Materials Co., Ltd., Hangzhou, Zhejiang, China) $100 \mathrm{U} / \mathrm{mL}$ penicillin, and $100 \mu \mathrm{g} / \mathrm{mL}$ streptomycin (Gibco, Thermo Fisher Scientific) at $37^{\circ} \mathrm{C}$ in a $5 \% \mathrm{CO}_{2}$ atmosphere in a constant-temperature incubator (thermo371, Thermo Fisher Scientific, New York, NY, USA).

\subsection{Oxidative Damage Model}

$293 \mathrm{~T}$ cells at a density of $1 \times 10^{5}$ were seeded in 96-well plates and incubated at $37^{\circ} \mathrm{C}$ for $24 \mathrm{~h}$. The original medium was removed, cells were stimulated with different concentrations of $\mathrm{H}_{2} \mathrm{O}_{2}(0,100$, 200, 300, 400, 500, 600, and $700 \mu \mathrm{mol} / \mathrm{L}$ ), and after 1, 2, and $3 \mathrm{~h}$, cell viability was measured by the CCK-8 (Solarbio Life Sciences, Beijing, China) method.

\subsection{Apoptosis Model}

HepG 2 cells at a density of $1 \times 10^{5}$ were inoculated into a 96-well culture plate and cultured in a cell culture incubator for $24 \mathrm{~h}$. The original medium was removed, and different concentrations 
of KFSE were added to stimulate the cells for $48 \mathrm{~h}(0,100,200,300,400,500,600$, and $700 \mu \mathrm{mol} / \mathrm{L}$, we defined the fermented original solution to be $1 \mathrm{~mol} / \mathrm{L})$. Each condition was repeated three times. The cell viability was measured by the CCK-8 method.

\subsection{Flow Cytometry}

A total of $1 \times 10^{6} 293 \mathrm{~T}$ cells and HepG2 cells respectively plated in 6-well plates and starved for $24 \mathrm{~h}$ in serum-free medium before treatment, allowing cell division to synchronize. The cells in the oxidative damage group were treated with KFSE $(200 \mu \mathrm{mol} / \mathrm{L})$ for $48 \mathrm{~h}$, and then $\mathrm{H}_{2} \mathrm{O}_{2}(100 \mu \mathrm{mol} / \mathrm{L})$ was added to induce damage for $2 \mathrm{~h}$. Apoptotic cells were treated with KFSE for $48 \mathrm{~h}$. Then removed the medium and washed cells twice with pre-cooled phosphate-buffered saline (PBS). Flow cytometry (AccuriC6, BD Biosciences, San Jose, CA, USA) was used to detect apoptosis and the cell cycle according to the kit instructions (Yeasen, Shanghai, China).

\subsection{RNA Extraction and qRT-PCR}

293T and HepG2 cells were grown to 70-80\% confluency for extraction and were treated with KFSE for $48 \mathrm{~h}$. Then, $\mathrm{H}_{2} \mathrm{O}_{2}$ was used to induce oxidative damage for $2 \mathrm{~h}$, and the apoptotic group was not treated. Cells were lysed using assay kits (BiaMaiKe; Beijing, China), and total RNA was extracted. RNA concentrations were determined using a micro-spectrophotometer (Nano-300, Hangzhou Allsheng Instruments Co., Ltd., Hangzhou, Zhejiang, China). One microgram of RNA was used for cDNA synthesis using the RevertAid First Strand cDNA Synthesis Kit (Thermo Fisher Scientific Baltics UAB, Vilnius, Lithuania). RT-PCR was performed in a HieffTM qPCR SYBR ${ }^{\circledR}$ Green master mix (High Rox Plus; Yeasen, Shanghai, China) with a Step One Plus Real-Time PCR System (Thermo Fisher Scientific, New York, NY, USA). Test gene Ct values were normalized to Ct values of the housekeeping gene GAPDH, and fold differences compared to those of untreated controls were calculated. RT-qPCR was performed using the following cycling conditions: Predenaturation at $95{ }^{\circ} \mathrm{C}$ for $3 \mathrm{~min}$, followed by 40 cycles of denaturation at $95^{\circ} \mathrm{C}$ for $30 \mathrm{~s}$, annealing at $\mathrm{X}^{\circ} \mathrm{C}$ for $30 \mathrm{~s}$ (X means the annealing temperature, which was determined by gradient PCR (A200 Gradient Thermal cycle, Zhejiang LongGene Scientific Instrument Co., Ltd., Hangzhou, Zhejiang, China)), and extension at $72{ }^{\circ} \mathrm{C}$ for $30 \mathrm{~s}$. The corresponding annealing temperature information and primer sequence information are as shown in the Appendix A (Table A1).

\subsection{Protein Isolation and Western Blotting Analysis}

A total of $1 \times 10^{7} 293 \mathrm{~T}$ and HepG2 cells were cultured for $24 \mathrm{~h}$, washed with cold PBS, and then lysed with $200 \mu \mathrm{L}$ of radio immunoprecipitation assay (RIPA) buffer and $2 \mu \mathrm{L}$ of phenylmethanesulfonyl fluoride (PMSF; Easy Bio, Beijing, China). Proteins (20 $\mu \mathrm{g})$ were separated using 12\% sodium dodecyl sulfate-polyacrylamide gel electrophoresis (SDS-PAGE; Whatman Schleicher and Schuell, Keene, NH, USA) and transferred to nitrocellulose membranes (PVDF, Thermo Fisher Scientific, Waltham, MA, USA). The membranes were blocked using 5\% milk and probed with anti-SOD, CAT, GSH, GSH-Px, Bax, NF-kB, and Caspase8 (Invitrogen, Thermo Fisher Scientific, RockFord, USA; 1:1000 diluted in 5\% milk) overnight at $4{ }^{\circ} \mathrm{C}$. After washing with $1 \times$ TBST (Solarbio Life Sciences, Beijing, China) five times, the blots were treated with a second antibody (Cell Signaling Technology Inc., Danvers, MA, USA) for $1 \mathrm{~h}$ and washed with $1 \times$ TBST five times. Proteins were detected by enhanced chemiluminescence (ECL) HRP substrates (Solarbio Life Sciences, Beijing, China), and the expression was imaged using a Tanon 6200 Luminous Imaging Workstation (Tanon Science and Technology Co., Ltd., Shanghai, China). Western blot analysis was performed on total cell lysate. Semiquantitative analysis of protein expression was performed using ImageJ 1.44 software (National Institutes of Health, Bethesda, MD, USA).

\subsection{High-Performance Liquid Chromatography (HPLC)}

Standards for p-hydroxycinnamic acid, neochlorogenic acid, chlorogenic acid, rutin, polydatin, rosmarinic acid, and epicatechin gallate (EGCG; Shanghai Yuanye Biotechnology Co., Ltd. Shanghai, 
China) were weighed accurately, and a $0.1 \mathrm{mg} / \mathrm{mL}$ solution was prepared using methanol. Grape skin fermentation solution produced by lactic acid bacteria was extracted with a HyperSep C18 column (Thermo Scientific, 320 Rolling ridge Drive, Bellefonte, PA.), eluted with methanol-water (1:1, $V / V)$, and filtered through a $0.22 \mu \mathrm{m}$ filter. Fermentation components were detected (UltiMate3000 HPLC System, Thermo Fisher Scientific) using the following chromatographic conditions: Accucore C18 column $(4.6 \mathrm{~mm} \times 150 \mathrm{~mm}, 2.6 \mu \mathrm{m}$, Thermo Fisher Scientific); flow rate of $0.5 \mathrm{~mL} / \mathrm{min}$; detection wavelength of $285 \mathrm{~nm}$; injection volume of $10 \mathrm{~L}$; column temperature of $30^{\circ} \mathrm{C}$; collection time of $75 \mathrm{~min}$; acetonitrile for mobile phase A (Thermo Fisher Scientific, USA); and 0.1\% aqueous acetic acid solution for mobile phase $B$. The gradient elution conditions are shown in Table 1.

Table 1. Flow phase gradient elution program.

\begin{tabular}{ccc}
\hline $\mathbf{t} / \mathbf{m i n}$ & $\mathbf{A} \%$ & $\mathbf{B} \%$ \\
\hline $0-20$ & $97-95$ & $3-5$ \\
$20-35$ & $95-85$ & $5-15$ \\
$35-50$ & $85-70$ & $15-30$ \\
$50-65$ & $70-70$ & $30-30$ \\
$65-75$ & $70-0$ & $30-0$ \\
\hline
\end{tabular}

\subsection{Statistical Analysis}

The data were statistically analyzed by SPASS 17.0 and GraphPad Prism 7 statistical software. Experimental results are expressed as the mean \pm standard deviation (SD). One-way ANOVA or $t$-test was used for comparison between groups. $p \leq 0.05$ indicated that the difference was statistically significant.

\section{Results}

\subsection{Antioxidant Activity In Vitro}

As depicted in Figure 1A,B, the antioxidant capacity of KFSE was stronger than that extracted by ethanol. KFSE achieved the maximum anti-DPPH and ABTS effects after $96 \mathrm{~h}$ of fermentation, reaching $90.84 \%$ and $81.38 \%$, respectively. Moreover, the effect of KFSE was also stronger than that of BFSE and WS. This indicated that LP-KFY02 probiotics could significantly improve the antioxidant effect of the fermentation solution after fermenting the grape skin.
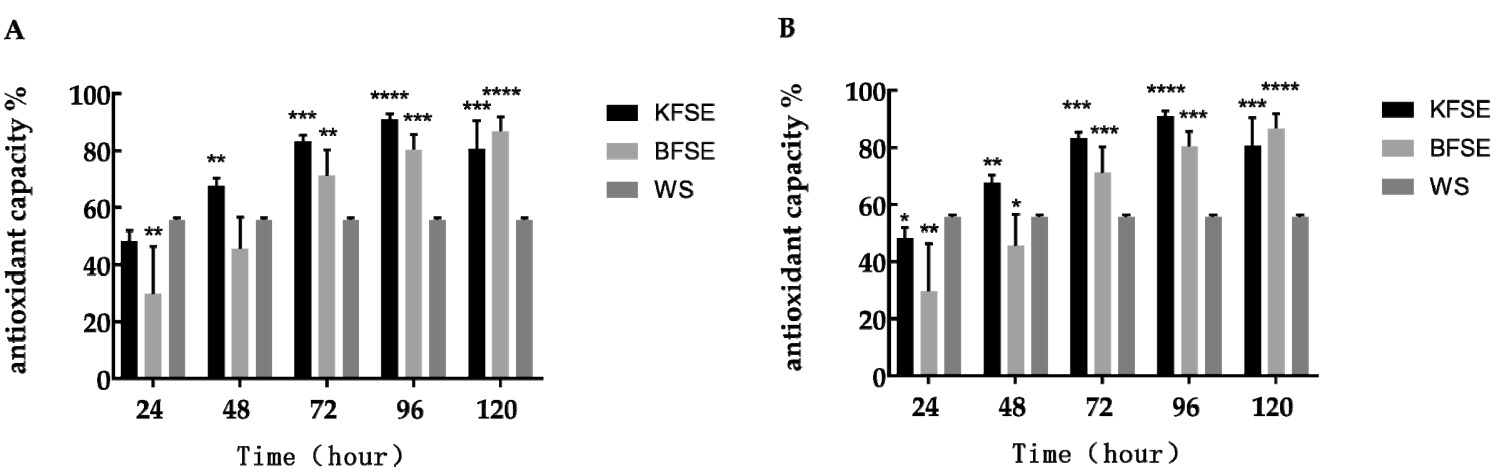

Figure 1. In vitro antioxidant activities of each experimental group. (A) Resistance of each experimental group to DPPH during different time intervals (24, 48, 72, 96, and $120 \mathrm{~h}$ ). (B) Resistance of each experimental group to ABTS during different time intervals $(24,48,72,96$, and $120 \mathrm{~h})$. Values presented are the means \pm standard deviation $(N=3$ /group). KFSE: The fermentation solution fermented by Lactobacillus plantarum (LP)-KFY02; BFSE: The fermentation solution fermented by Lactobacillus delbrueckii subsp. bulgaricus; and WS: The solution extracted by ethanol. * stands for $p<0.05,{ }^{* *}$ stands for $0.05 \leq p$ $<0.01,{ }^{* * * *}$ stands for $0.01 \leq p<0.001$, and ${ }^{* * * *}$ stands for $0.001 \leq p<0.0001$. 


\section{2. $\mathrm{H}_{2} \mathrm{O}_{2}$-Induced Oxidative Damage and Effects of KFSE on Human Embryonic Kidney (293T) Cell}

As depicted in Figure 2A, $\mathrm{B}, \mathrm{H}_{2} \mathrm{O}_{2}$ significantly inhibited the growth of $293 \mathrm{~T}$ cells in time-dependent and concentration-dependent manners. The inhibitory effect of $\mathrm{H}_{2} \mathrm{O}_{2}$ at $200 \mu \mathrm{mol} / \mathrm{L}$ on 293T cells reached $54.67 \%$ after $2 \mathrm{~h}$. In addition, in a concentration range (100-400 $\mu \mathrm{mol} / \mathrm{L}), \mathrm{KFSE}$ promoted the growth of 293T cells, and the proliferation rate of 293T cells with KFSE at a concentration of $200 \mu \mathrm{mol} / \mathrm{L}$ was $124.70 \%$. This effect was better than that of BFSE and WS, and cell proliferation was inhibited when the concentration exceeded $400 \mu \mathrm{mol} / \mathrm{L}$.
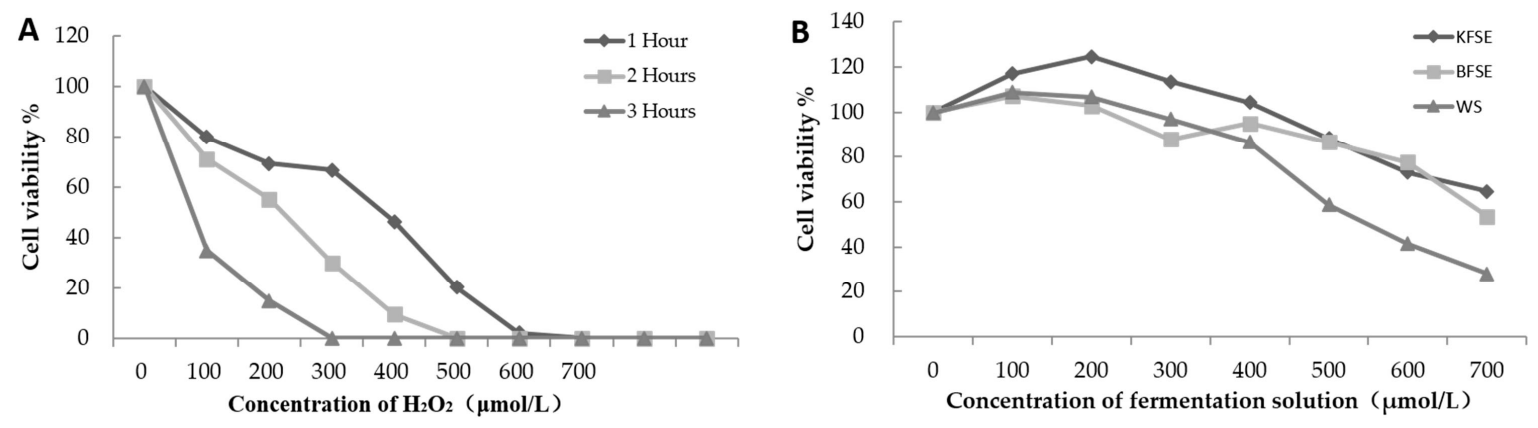

Figure 2. The oxidative damage model and the promotion of cell functions. (A) The trend in cell survival rate with time and concentration. (B) Effect of treatment with grape skin fermentation solution for $48 \mathrm{~h}$ on the growth viability of 293T cells. KFSE: The fermentation solution fermented by LP-KFY02; BFSE: The fermentation solution fermented by Lactobacillus delbrueckii subsp. bulgaricus; and WS: The solution extracted by ethanol.

\subsection{Effect of KFSE on Human Embryonic Kidney (293T) Cell Morphology}

After culturing 293T cells with $200 \mu \mathrm{mol} / \mathrm{L}$ of KFSE for $48 \mathrm{~h}$, the cells were exposed to $\mathrm{H}_{2} \mathrm{O}_{2}$ for $2 \mathrm{~h}$ at a concentration of $100 \mu \mathrm{mol} / \mathrm{L}$, and the morphology of the cells was observed under an inverted microscope. As shown in Figure 3, the normal 293T cells were full of cells, rich in cytoplasm, numerous in number, and polygonal in shape, with pseudo-foot-like staggered around them. In the $\mathrm{H}_{2} \mathrm{O}_{2}$ induction model group, the cells were severely shrunken, the number of cells was reduced, and the damage was severe. The number of cells in the KFSE treatment group was increased, the cell state was good; in response to $\mathrm{H}_{2} \mathrm{O}_{2}$-induced oxidation, the protective effects of KFSE showed apparent improvement in cell body shrinkage, an increase in the number of cells, and a reduction in the degree of damage. BFSE and WS also had protective effects against oxidative damage but were not as effective as KFSE. The results indicated that KFSE could protect $293 \mathrm{~T}$ cells from oxidative damage.

\subsection{Oxidation Index of the Human Embryonic Kidney (293T) Cell}

We demonstrated in Table 2 that compared with the oxidation index of the normal, in our damage model, the representative oxidation index levels of SOD, CAT, GSH, and GSH-Px were decreased and the levels of MAD, NO, and LDH were increased. Conversely, KFSE significantly increased the index levels of SOD, CAT, GSH, GSH-Px, and T-AOC and decreased the levels of MAD, NO, and LDH, which were damaged by $\mathrm{H}_{2} \mathrm{O}_{2}$. Moreover, there was no significant difference from the other groups. Therefore, we certified that KFSE could protect cells from oxidative damage and maintain the relevant indicators at normal levels.

3.5. KFSE Promotes SOD, CAT, GSH, and GSH-Px mRNA and Protein Expression in the Human Embryonic Kidney (293T) Cell

Table 3 shows that SOD, CAT, GSH, and GSH-Px mRNA (messenger RNA) levels decreased compared with normal levels. Compared with the control, KFSE significantly increased the expression of $S O D, C A T, G S H$, and GSH-Px, which play representative roles in oxidative damage of cells. Moreover, the expression of other products was also significantly affected after $48 \mathrm{~h}$ when compared with that of 
the control. The same result was also found in the protein expression level (Figure 4). We showed that KFSE increased SOD, CAT, GSH, and GSH-Px protein expression after $\mathrm{H}_{2} \mathrm{O}_{2}$ damage. In addition, BFSE and WS also significantly increased the protein levels of SOD, CAT, GSH, and GSH-Px compared with that of the model. Overall, our results confirmed the protective effect of KFSE in 293T oxidative damage.

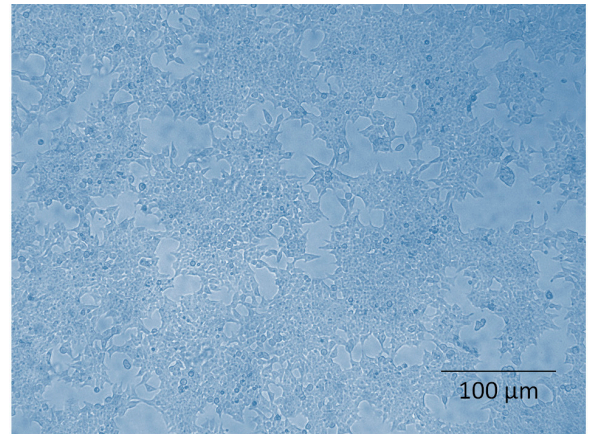

Normal

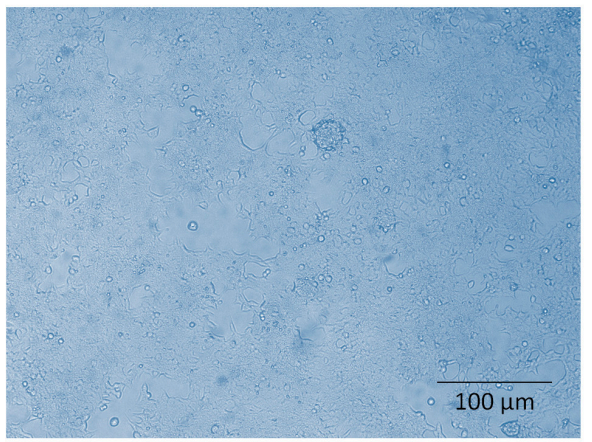

KFSE

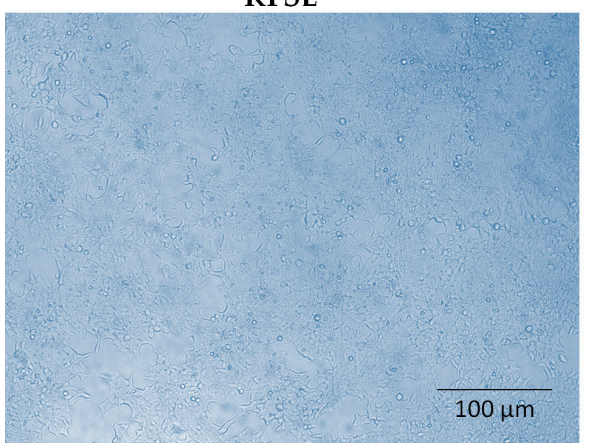

BFSE

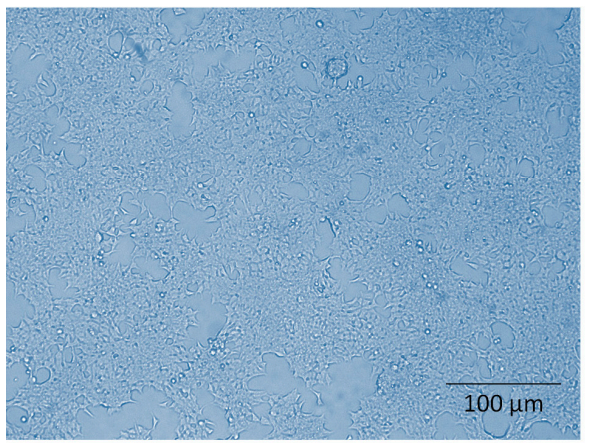

WS

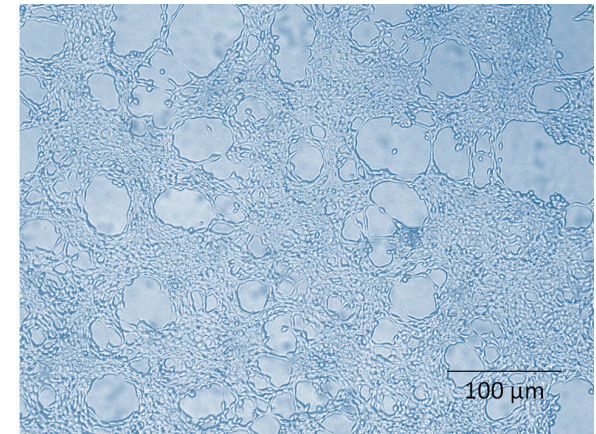

Control

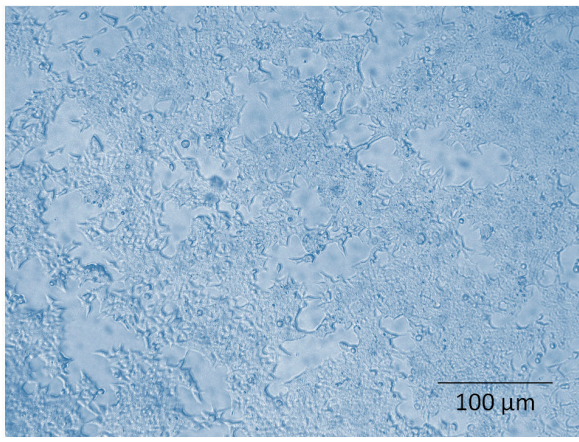

KFSE treat with $\mathrm{H}_{2} \mathrm{O}_{2}$

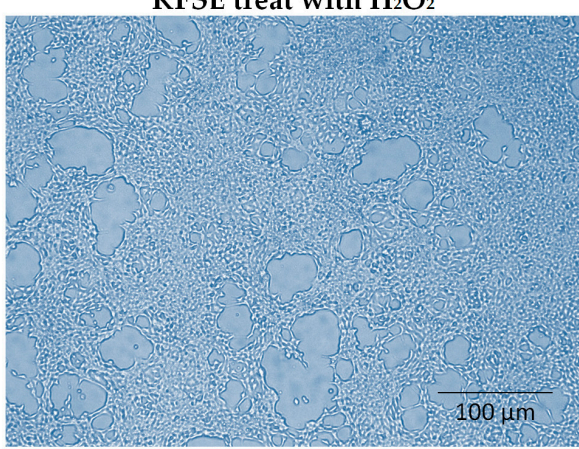

BFSE treat with $\mathrm{H}_{2} \mathrm{O}_{2}$

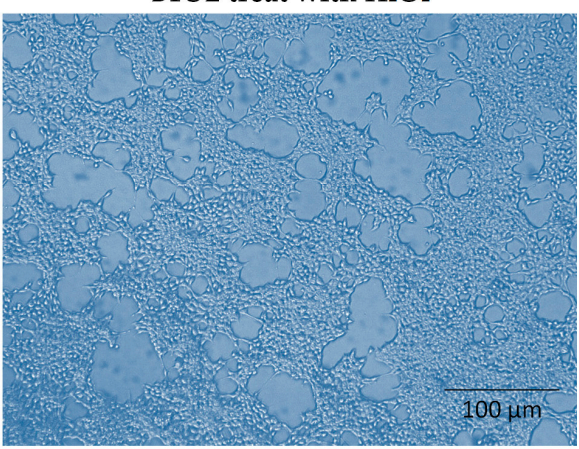

WS treat with $\mathrm{H}_{2} \mathrm{O}_{2}$

Figure 3. Effect of grape skin fermentation solution on 293T cell morphology (200×). KFSE: The fermentation solution fermented by LP-KFY02; BFSE: The fermentation solution fermented by Lactobacillus delbrueckii subsp. bulgaricus; and WS: The solution extracted by ethanol. 
Table 2. LDH, GSH, GSH-Px, CAT, MDA, SOD, T-AOC, and NO content in 293T cells.

\begin{tabular}{|c|c|c|c|c|c|c|c|c|}
\hline Group & $\begin{array}{c}\text { LDH } \\
\left(\mathrm{U} / 10^{4}\right)\end{array}$ & $\underset{\left(\mu \mathrm{g} / 10^{4}\right)}{\mathrm{GSH}}$ & $\begin{array}{c}\text { GSH-Px } \\
\text { (U/mg prot) }\end{array}$ & $\begin{array}{c}\text { CAT } \\
\left(\mathrm{U} / 10^{4}\right)\end{array}$ & $\begin{array}{c}\text { MDA } \\
\left(\mathrm{nmol}^{\prime} 10^{4}\right)\end{array}$ & $\begin{array}{c}\text { SOD } \\
\left(\mathrm{U} / 10^{4}\right)\end{array}$ & $\begin{array}{l}\text { T-AOC } \\
\left(\mathrm{U} / 10^{4}\right)\end{array}$ & $\begin{array}{c}\text { NO } \\
\left(\mu \mathrm{mol} / 10^{4}\right)\end{array}$ \\
\hline Normal & $5.44 \pm 0.16^{\mathrm{a}}$ & $3.13 \pm 0.14^{c}$ & $2.50 \pm 0.20^{c}$ & $2.77 \pm 0.21^{c}$ & $1.42 \pm 0.04^{\mathrm{a}}$ & $18.12 \pm 0.61^{\mathrm{d}}$ & $18.32 \pm 0.79^{d}$ & $4.20 \pm 0.39^{\mathrm{a}}$ \\
\hline Control & $8.90 \pm 0.33^{c}$ & $1.89 \pm 0.07^{\mathrm{a}}$ & $0.91 \pm 0.11^{\mathrm{a}}$ & $1.43 \pm 0.10^{\mathrm{a}}$ & $2.72 \pm 0.17^{c}$ & $10.46 \pm 0.57^{a}$ & $11.42 \pm 0.16^{\mathrm{a}}$ & $8.43 \pm 0.49^{c}$ \\
\hline KFSE & $6.56 \pm 0.64^{b}$ & $2.72 \pm 0.07^{b}$ & $1.80 \pm 0.07^{b}$ & $2.06 \pm 0.09^{b}$ & $1.68 \pm 0.06^{b}$ & $16.99 \pm 0.19^{c}$ & $15.92 \pm 0.25^{c}$ & $5.62 \pm 0.12^{b}$ \\
\hline BFSE & $7.40 \pm 0.45^{b}$ & $2.76 \pm 0.27^{b}$ & $1.62 \pm 0.08^{b}$ & $1.95 \pm 0.11^{b}$ & $1.75 \pm 0.09^{b}$ & $16.63 \pm 0.32^{c}$ & $14.62 \pm 1.22^{b}$ & $4.38 \pm 0.66^{\mathrm{a}}$ \\
\hline WS & $7.41 \pm 0.40^{b}$ & $2.67 \pm 0.24^{b}$ & $1.72 \pm 0.03^{b}$ & $1.88 \pm 0.05^{b}$ & $1.79 \pm 0.08^{b}$ & $15.73 \pm 0.47^{b}$ & $13.40 \pm 0.31^{b}$ & $5.29 \pm 0.25^{b}$ \\
\hline
\end{tabular}

Table 3. The mRNA expression of SOD, GSH, CAT and GSH-Px in 293T cells.

\begin{tabular}{ccccc}
\hline Group & CAT & SOD & GSH & GSH-Px \\
\hline Normal & $1.01 \pm 0.18^{\mathrm{c}}$ & $1.00 \pm 0.09^{\mathrm{d}}$ & $1.00 \pm 0.09^{\mathrm{c}}$ & $1.01 \pm 0.18^{\mathrm{c}}$ \\
Control & $0.39 \pm 0.08^{\mathrm{a}}$ & $0.12 \pm 0.01^{\mathrm{a}}$ & $0.32 \pm 0.03^{\mathrm{a}}$ & $0.35 \pm 0.04^{\mathrm{a}}$ \\
KFSE & $1.11 \pm 0.08^{\mathrm{c}}$ & $0.57 \pm 0.09^{\mathrm{c}}$ & $1.07 \pm 0.13^{\mathrm{c}}$ & $1.22 \pm 0.08^{\mathrm{c}}$ \\
BFSE & $0.66 \pm 0.13^{\mathrm{b}}$ & $0.30 \pm 0.03^{\mathrm{b}}$ & $0.97 \pm 0.08^{\mathrm{c}}$ & $0.72 \pm 0.14^{\mathrm{b}}$ \\
WS & $0.66 \pm 0.04^{\mathrm{b}}$ & $0.28 \pm 0.08^{\mathrm{b}}$ & $0.81 \pm 0.06^{\mathrm{b}}$ & $0.54 \pm 0.16^{\mathrm{a}, \mathrm{b}}$ \\
\hline
\end{tabular}

a-d Mean values with different letters in the same column differ significantly $(p<0.05)$ by Duncan's multiple range test. Values presented are the means \pm standard deviation ( $N=3$ /group). KFSE: The fermentation solution fermented by LP-KFY02; BFSE: The fermentation solution fermented by Lactobacillus delbrueckii subsp. bulgaricus; and WS: The solution extracted by ethanol.

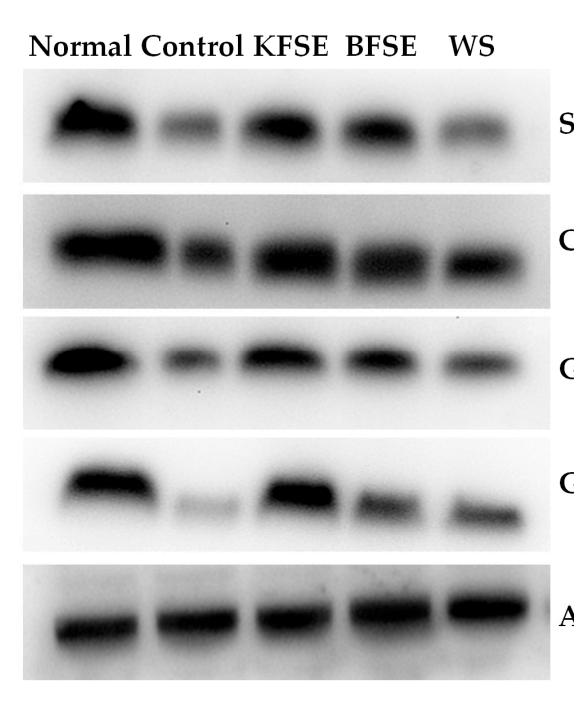

SOD
CAT
GSH
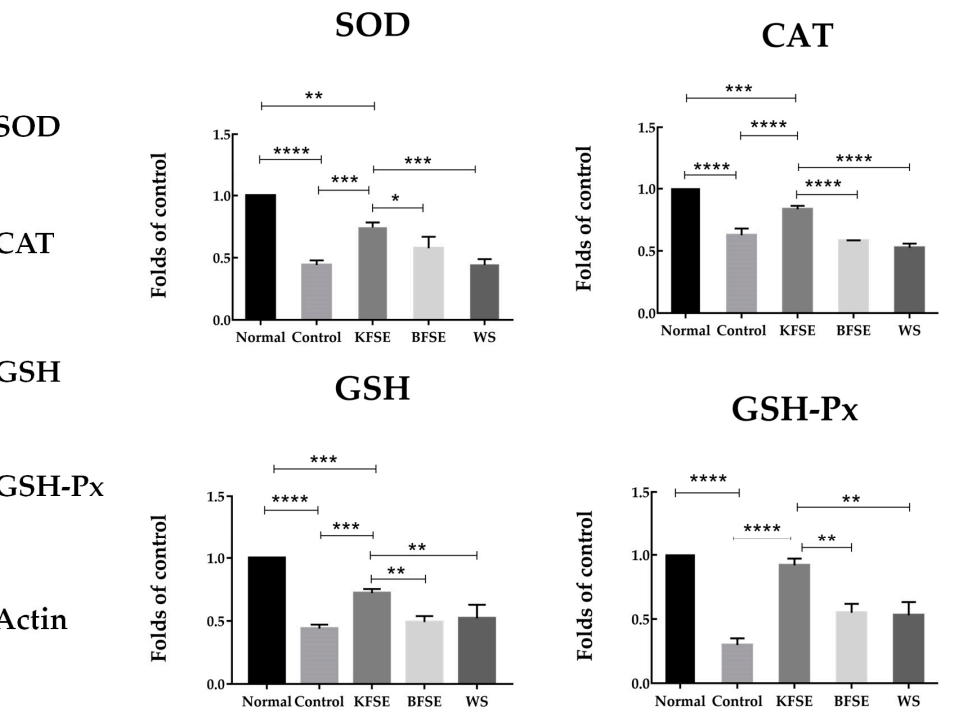

Figure 4. SOD, GSH, CAT, and GSH-Px protein expression in $293 \mathrm{~T}$ cells. Values presented are the means \pm standard deviation ( $N=3$ /group). KFSE: The fermentation solution fermented by LP-KFY02; BFSE: The fermentation solution fermented by Lactobacillus delbrueckii subsp. bulgaricus; and WS: The solution extracted by ethanol. ${ }^{*}$ stands for $p<0.05,{ }^{* *}$ stands for $0.05 \leq p<0.01,{ }^{* * * *}$ stands for $0.01 \leq p<$ 0.001 , and ${ }^{* * * *}$ stands for $0.001 \leq p<0.0001$.

\subsection{KFSE Inhibits Human Hepatoma (HepG2) Cells Growth In Vitro}

As depicted in Figure 5 KFSE significantly inhibited HepG2 cell growth by over $50 \%$ at a concentration of $300 \mu \mathrm{mol} / \mathrm{L}$ after $48 \mathrm{~h}$ and was sustained several concentrations. The significant inhibition was dose dependent (Figure 5A). The morphology of the cells is shown in Figure 5B. Compared with the morphology of the control group, the cells shrunk and shattered after KFSE treatment and reached over $50 \%$ apoptosis at $300 \mu \mathrm{mol} / \mathrm{L}$ for $48 \mathrm{~h}$. The similar phenomena also appeared in the BFSC and WS. After a treatment with BFSE and WS for $48 \mathrm{~h}$, we found that the morphology of cells was shrunk, the 
nucleus was obvious, the growth rate decreased, and cells exhibited varying degrees of shattered. We demonstrated significant growth inhibition in HepG2 liver cells.

(A)

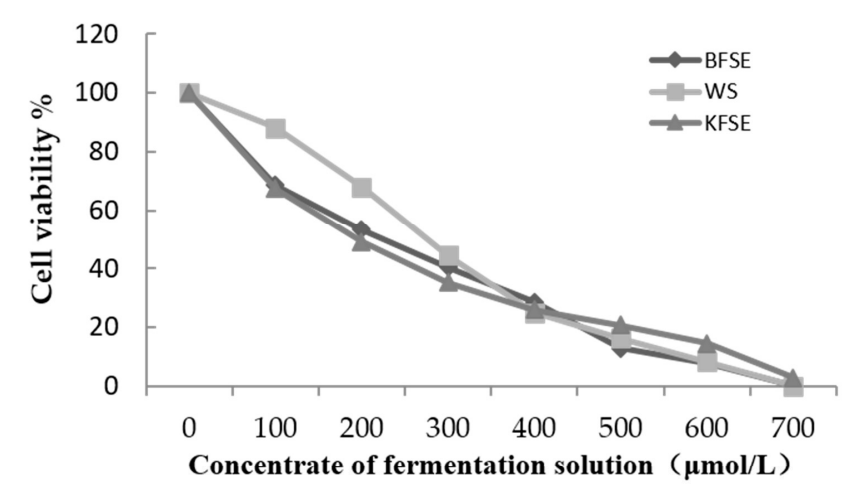

(B)

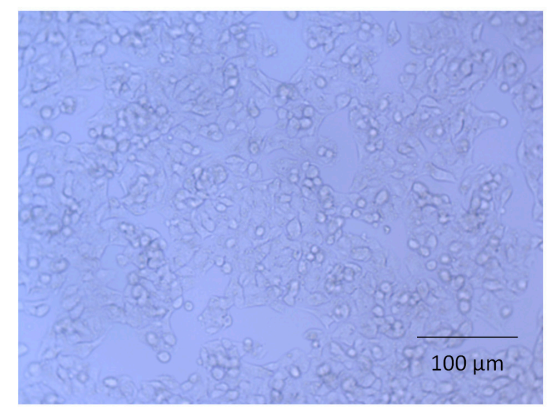

Normal

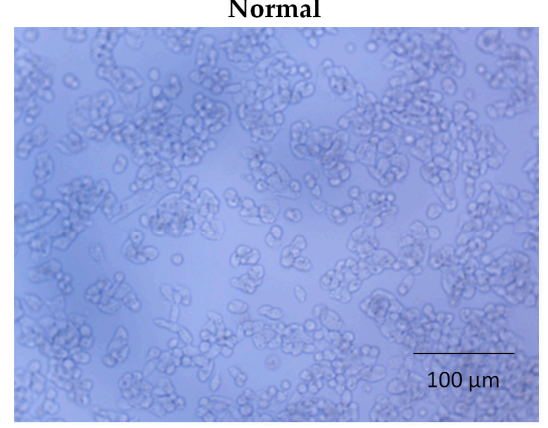

BFSE

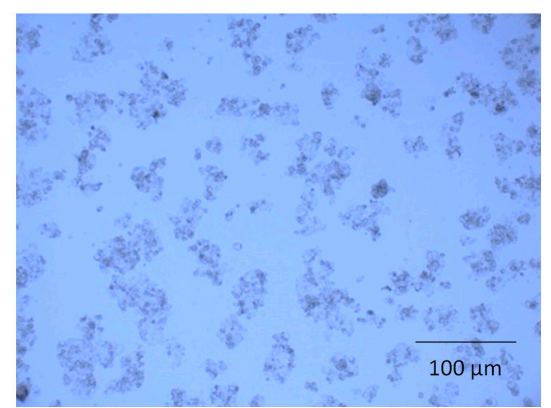

KFSE

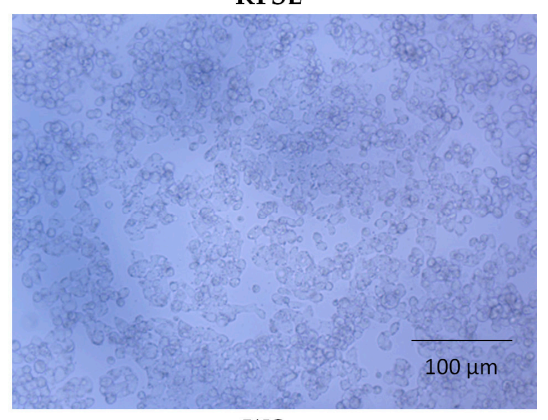

WS

Figure 5. Effect of KFSE on HepG2 cell survival rate and the effect on cell morphology. (A) Effect of treatment with grape skin fermentation solution for $48 \mathrm{~h}$ on the survival rate of HepG2 cells. (B) Effect of treatment with grape skin fermentation solution for $48 \mathrm{~h}$ on the morphology of HepG2 cells (200x). KFSE: The fermentation solution fermented by LP-KFY02; BFSE: The fermentation solution fermented by Lactobacillus delbrueckii subsp. bulgaricus; and WS: The solution extracted by ethanol.

\subsection{KFSE Induces Cell Cycle Arrest in Human Hepatoma (HepG2) Cells}

Cell cycle analysis demonstrated that KFSE significantly $(p \leq 0.05)$ arrested cells during the G1 to G2 phase transition at $300 \mu \mathrm{mol} / \mathrm{L}$ KFSE compared to that of the control after $48 \mathrm{~h}$ (Figure 6). Moreover, PI analysis demonstrated that KFSE also significantly induced apoptosis. This was confirmed by Annexin V-FITC/PI analysis (FITC: Fluorescein Isothiocyanate, PI: Propidium Iodide) (Figure 6). After KFSE treatment of HepG2 cells for $48 \mathrm{~h}$, the detectable cell survival rate was only $24 \%$, and more than $53.4 \%$ of cells were in advanced apoptosis and complete apoptosis. 

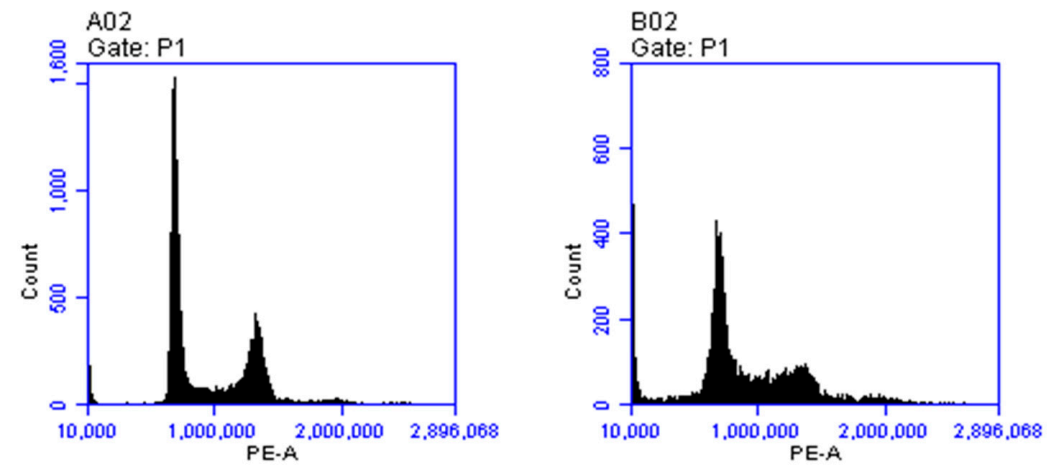

Normal

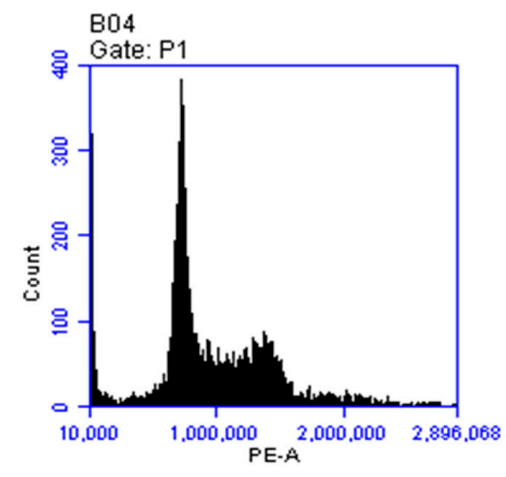

KFSE

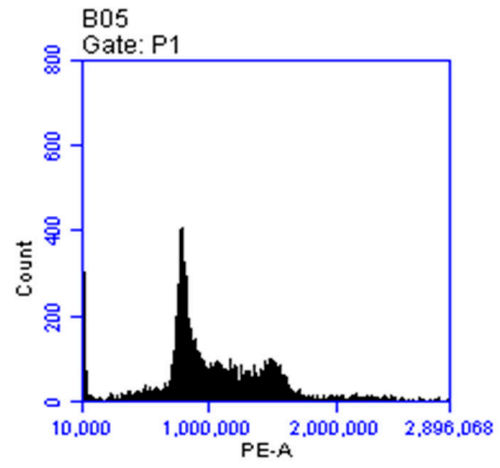

BFSE

WS
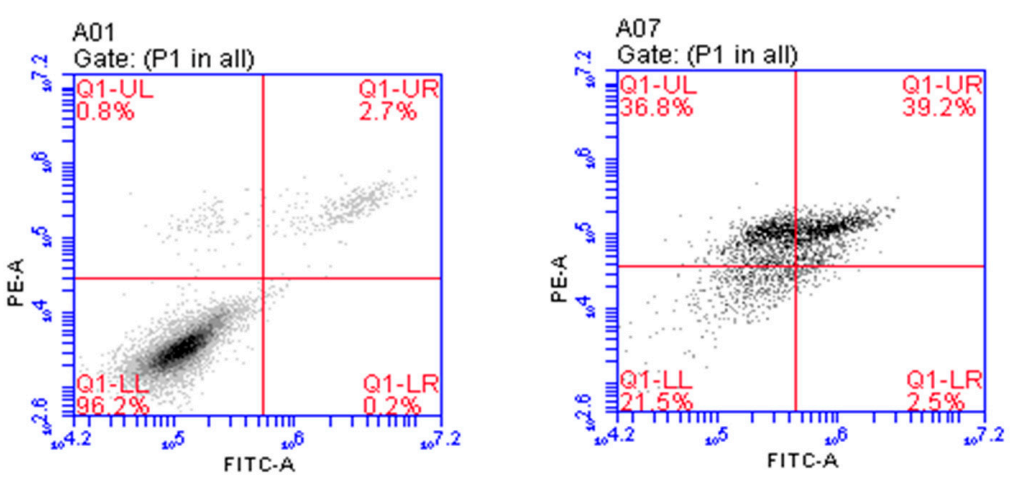

Normal

KFSE
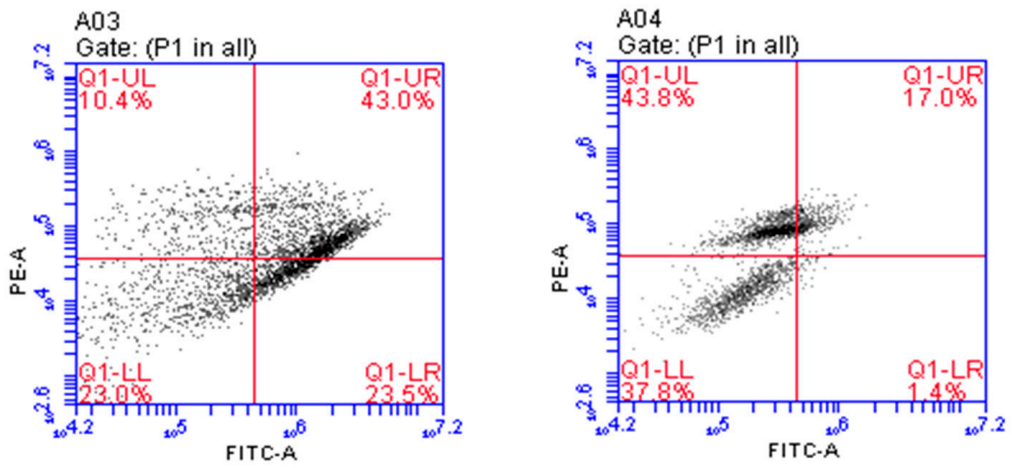

BFSE

WS

Figure 6. The effect of fermentation solution on the HepG2 cell cycle and apoptosis. KFSE: The fermentation solution fermented by LP-KFY02; BFSE: The fermentation solution fermented by Lactobacillus delbrueckii subsp. bulgaricus; and WS: The solution extracted by ethanol. 


\subsection{Protein Expression and mRNA Expression in Human Hepatoma (HepG2) Cells}

As shown in Tables 4-6 compared with levels in the normal group, the mRNA expression levels of $B c l-2, c o x-2, P C N A, c y c l i n-D 1, C-m y c, C D K 4, N F-\kappa B$, and $p R B 1$ in the KFSE group were significantly lower, and the expression levels of Caspase-3, Caspase-7, Caspase-8, Caspase-9, p53, TNF- $\alpha$, and p21 were higher. We showed that KFSE induced expression of $p 53$, which is the key gene in apoptosis, and leads to the up-regulation of $p 21$ expression. The results were consistent with KFSE, which we found to promote apoptosis and blockade of hepatoma cells.

Table 4. The mRNA expression of Bcl-2, cox-2, Caspase-3, Caspase-7, and Caspase-8 in HepG2 cells.

\begin{tabular}{cccccc}
\hline Group & Bcl-2 & cox-2 & Caspase-3 & Caspase-7 & Caspase-8 \\
\hline Normal & $1.01 \pm 0.16^{\mathrm{c}}$ & $1.01 \pm 0.13^{\mathrm{b}}$ & $1.01 \pm 0.13^{\mathrm{a}}$ & $1.00 \pm 0.05^{\mathrm{a}}$ & $1.13 \pm 0.61^{\mathrm{a}}$ \\
KFSE & $0.60 \pm 0.08^{\mathrm{a}} \downarrow$ & $0.72 \pm 0.10^{\mathrm{a}} \downarrow$ & $2.25 \pm 0.56^{\mathrm{b}} \uparrow$ & $3.39 \pm 0.39^{\mathrm{c}} \uparrow$ & $3.52 \pm 1.07^{\mathrm{b}} \uparrow$ \\
BFSE & $0.92 \pm 0.11 \mathrm{~b}^{\mathrm{c}} \downarrow$ & $0.76 \pm 0.03^{\mathrm{a}} \downarrow$ & $1.90 \pm 0.37^{\mathrm{b}} \uparrow$ & $1.14 \pm 0.18^{\mathrm{a}} \uparrow$ & $2.57 \pm 1.87^{\mathrm{a}, \mathrm{b}} \uparrow$ \\
WS & $0.81 \pm 0.07^{\mathrm{b}} \downarrow$ & $0.76 \pm 0.04^{\mathrm{a}} \downarrow$ & $1.77 \pm 0.08^{\mathrm{b}} \uparrow$ & $2.57 \pm 0.88^{\mathrm{b}} \uparrow$ & $1.43 \pm 0.13^{\mathrm{a}} \uparrow$ \\
\hline
\end{tabular}

a-d Mean values with different letters in the same column differ significantly $(p<0.05)$ by Duncan's multiple range test. Values presented are the means \pm standard deviation ( $N=3$ /group). KFSE: The fermentation solution fermented by LP-KFY02; BFSE: The fermentation solution fermented by Lactobacillus delbrueckii subsp. bulgaricus; and WS: The solution extracted by ethanol.

Table 5. The mRNA expression of TGF- $\beta$, Caspase-9, C-Myc, CyclinD1, and CDK4 in HepG2 cells.

\begin{tabular}{cccccc}
\hline Group & TGF- $\beta$ & Caspase-9 & C-myc & cyclin-D1 & CDK4 \\
\hline Normal & $1.14 \pm 0.24^{\mathrm{a}}$ & $1.00 \pm 0.10^{\mathrm{a}}$ & $1.00 \pm 0.10^{\mathrm{a}}$ & $1.00 \pm 0.11^{\mathrm{c}}$ & $1.00 \pm 0.10^{\mathrm{d}}$ \\
KFSE & $3.18 \pm 0.17^{\mathrm{c}} \uparrow$ & $2.52 \pm 0.57^{\mathrm{d}} \uparrow$ & $1.19 \pm 0.13^{\mathrm{a}} \uparrow$ & $0.22 \pm 0.05^{\mathrm{a}} \downarrow$ & $0.31 \pm 0.04^{\mathrm{a}} \downarrow$ \\
BFSE & $5.41 \pm 0.87^{\mathrm{c}} \uparrow$ & $1.39 \pm 0.39^{\mathrm{b}} \uparrow$ & $1.11 \pm 0.24^{\mathrm{a}} \uparrow$ & $0.36 \pm 0.03^{\mathrm{b}} \downarrow$ & $0.60 \pm 0.06^{\mathrm{c}} \downarrow$ \\
WS & $3.71 \pm 1.07^{\mathrm{b}} \uparrow$ & $1.92 \pm 0.18^{\mathrm{c}} \uparrow$ & $1.17 \pm 0.17^{\mathrm{a}} \uparrow$ & $0.19 \pm 0.12^{\mathrm{a}} \downarrow$ & $0.49 \pm 0.04^{\mathrm{b}} \downarrow$ \\
\hline
\end{tabular}

${ }^{\mathrm{a}-\mathrm{d}}$ Mean values with different letters in the same column differ significantly $(p<0.05)$ by Duncan's multiple range test. Values presented are the means \pm standard deviation ( $N=3$ /group). KFSE: The fermentation solution fermented by LP-KFY02; BFSE: The fermentation solution fermented by Lactobacillus delbrueckii subsp. bulgaricus; and WS: The solution extracted by ethanol.

Table 6. The mRNA expression of NF- $\kappa B, p 21, p 53, P C N A$, and $p R B 1$ in HepG2 cells.

\begin{tabular}{cccccc}
\hline Group & NF- $\boldsymbol{\kappa} B$ & $p 21$ & $p 53$ & PCNA & $q R B 1$ \\
\hline Normal & $0.91 \pm 0.24^{\mathrm{b}}$ & $0.90 \pm 0.26^{\mathrm{a}}$ & $0.89 \pm 0.34^{\mathrm{a}}$ & $1.00 \pm 0.06^{\mathrm{b}}$ & $1.00 \pm 0.05^{\mathrm{c}}$ \\
KFSE & $0.58 \pm 0.08^{\mathrm{a}} \downarrow$ & $4.48 \pm 0.30^{\mathrm{c}} \uparrow$ & $2.27 \pm 0.25^{\mathrm{b}} \uparrow$ & $0.18 \pm 0.03^{\mathrm{a}} \downarrow$ & $0.15^{\mathrm{a}} \pm 0.05^{\mathrm{a}} \downarrow$ \\
BFSE & $0.63 \pm 0.09^{\mathrm{a}} \downarrow$ & $1.06 \pm 0.12^{\mathrm{a}} \uparrow$ & $1.18 \pm 0.30^{\mathrm{a}} \uparrow$ & $0.19 \pm 0.01^{\mathrm{a}} \downarrow$ & $0.13 \pm 0.02^{\mathrm{a}} \downarrow$ \\
WS & $0.57 \pm 0.11^{\mathrm{a}} \downarrow$ & $2.66 \pm 0.06^{\mathrm{b}} \uparrow$ & $1.97 \pm 0.18^{\mathrm{b}} \uparrow$ & $0.21 \pm 0.01^{\mathrm{a}} \downarrow$ & $0.26 \pm 0.05^{\mathrm{b}} \downarrow$ \\
\hline
\end{tabular}

${ }^{\mathrm{a}-\mathrm{d}}$ Mean values with different letters in the same column differ significantly $(p<0.05)$ by Duncan's multiple range test. Values presented are the means \pm standard deviation ( $N=3$ /group). KFSE: The fermentation solution fermented by LP-KFY02; BFSE: The fermentation solution fermented by Lactobacillus delbrueckii subsp. bulgaricus; and WS: The solution extracted by ethanol.

The levels of Bax, Caspase-8, and NF-kB proteins determined by western blot analysis are shown in Figure 7. Compared with the levels of the normal group, the protein levels of Bax and Caspase-8 in the KFSE treatment group were significantly increased, and the level of NF-kB protein was decreased. The same results were also found in the BFSE and WS treatment groups, which significantly increased levels of the apoptotic proteins Bax and Caspase 8 and decreased the protein expression of the inflammatory factor NF- $\mathrm{kB}$.

\subsection{Constituents of Fermentation Solution}

Figure 8 shows the polyphenol constituents of the fermented grape solution. As shown in Figure 8B, the total peak area of the fermentation solution fermented by LP-KFY02 was lower than that of the grape skin extract obtained from ethanol. Among them, the content of EGCG, rutin, and resveratrol 
in KFSE was the highest, reaching 25.54, 10.70, and $19.40 \mathrm{mAV}^{*} \mathrm{~min}$, respectively (Figure 8B), the extract obtained from ethanol obtained the highest rutin content, reached $37.73 \mathrm{mAV}$ min (Figure 8D). However, the effective peak of KFSE fermentation solution was 94, the effective peak of ethanol extract was 83 , and the active ingredient was more than ethanol extraction, while the fermentation result of BFSE only accumulated 59 effective peaks (Figure 8C). By standard reference comparison, the fermentation solutions included ECG, coumarin, new chlorogenic acid, rutin, resveratrol, chlorogenic acid, and rosmarinic acid (Figure $8 \mathrm{~A}$ ).

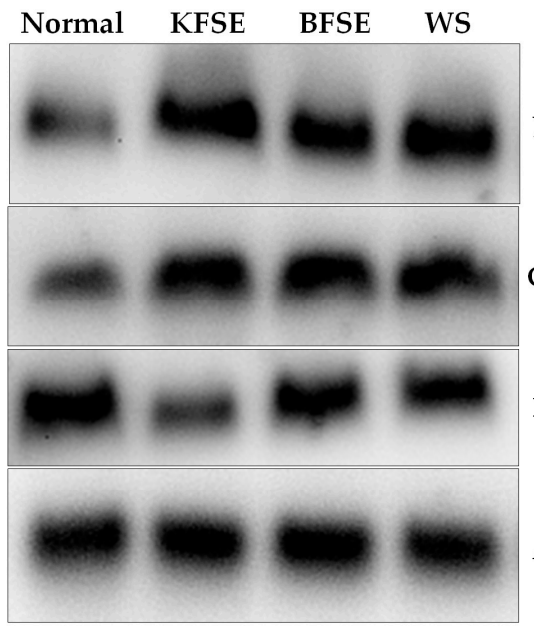

Caspase- 8
Bax
Bax

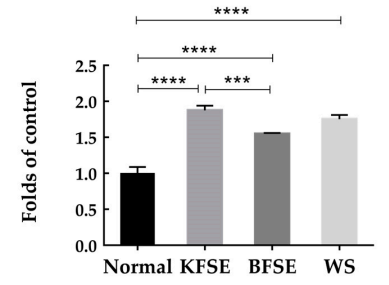

NF-^B

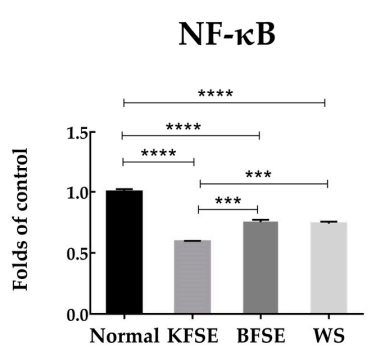

NF- $\ltimes B$

Actin
Caspase-8

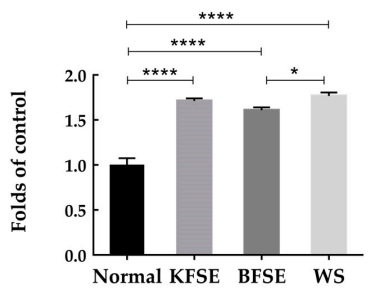

Figure 7. Bax, Caspase8, and NF-kB protein expression in HepG2 cells. Values presented are the means \pm standard deviation ( $N=3$ /group). KFSE: The fermentation solution fermented by LP-KFY02; BFSE: The fermentation solution fermented by Lactobacillus delbrueckii subsp. bulgaricus; WS: The solution extracted by ethanol. * stands for $p<0.05,{ }^{* *}$ stands for $0.05 \leq p<0.01$, ${ }^{* * *}$ stands for $0.01 \leq p<0.001$, and ${ }^{* * * *}$ stands for $0.001 \leq p<0.0001$.
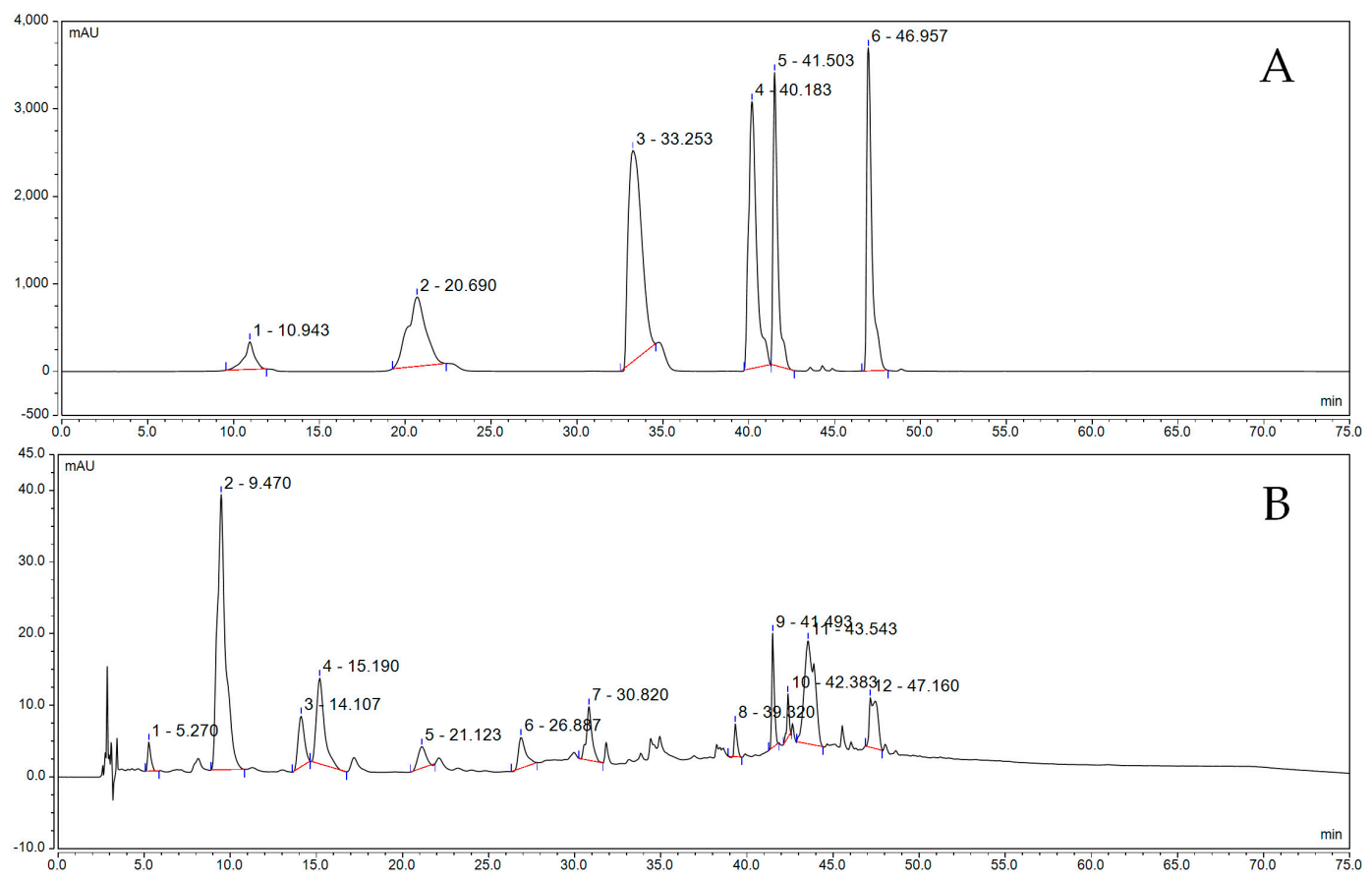

Figure 8. Cont. 

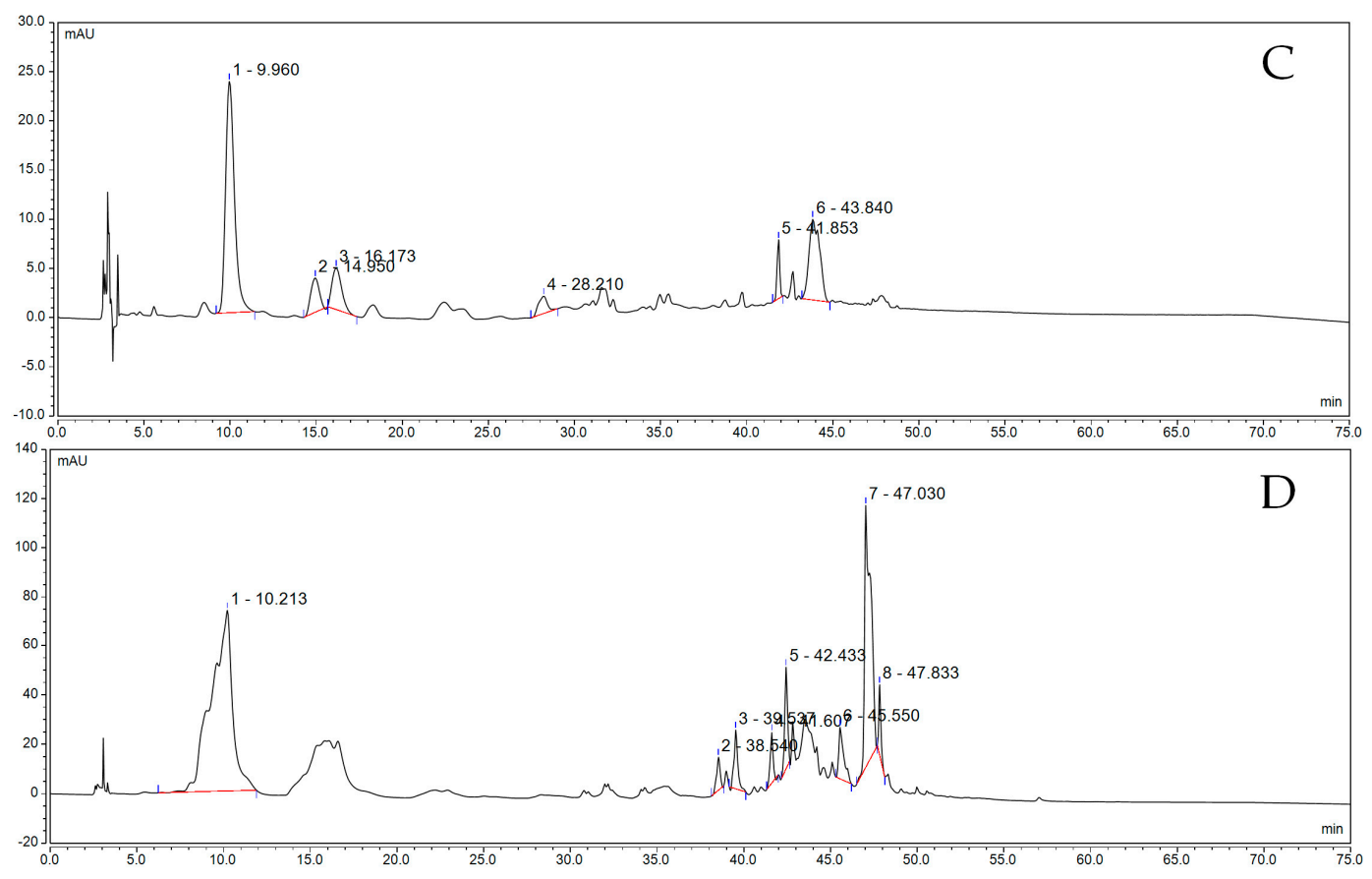

Figure 8. Polyphenol constituents of the fermented grape solution. (A) Standard chromatograms; (B) KFSE chromatograms; (C) BFSE chromatograms; and (D) WS chromatograms. 1: Epicatechin gallate (EGCG); 2: Coumarin; 3: New chlorogenic acid; 4: Rutin; 5: Resveratrol; and 6: Chlorogenic acid. KFSE: The fermentation solution fermented by LP-KFY02; BFSE: The fermentation solution fermented by Lactobacillus delbrueckii subsp. bulgaricus; and WS: The solution extracted by ethanol.

\section{Discussion}

This study examined whether KFSE was an antioxidant for human renal epithelial cells and an effective inhibitor of hepatoma in vitro. This study demonstrated that KFSE significantly inhibited cell growth of human hepatoma (HepG2) cells in vitro. This growth inhibition was accompanied by the induction of cell cycle arrest. Other studies have demonstrated significant growth-inhibitory effects by naturally occurring compounds in breast cancer cell lines. For example, Gupta et al. showed that Epigallocatechin gallate (EGCG) induced G1 phase arrest in human prostate carcinoma cells [20]. Comparable results were also observed after treatment with resveratrol in HT-29 cells [21] and quercetin in human osteosarcoma cells [22].

Oxidative damage is a key factor in the ageing, injury, and inflammation. Chronic diseases caused by oxidative damage, such as Alzheimer's disease, inflammation, and cancer, have always threatened people's lives. Bioflavonoids, polyphenols, vitamin C, anthocyanin, etc. are recognized as natural antioxidant products. It can effectively inhibit or alleviate the damage caused by oxidation and is of great significance for the treatment of various chronic diseases. Polyphenols are a group of compounds with a plurality of phenols per molecular unit and polyphenols are compounds that can be found in plants and have many health benefits. Many plants contain this type of compound and are most commonly found in flavonoids, phenolic acids, catechins, anthocyanins, isoflavones, quercetin, and resveratrol. Many studies have confirmed that these compounds always have a positive impact on human health.

Grapes and grape products, such as wine, grape seeds, and grape skin, which contain a variety of biophenolic and flavonoid substances, have generated remarkable interest based on positive reports of their antioxidant properties and ability to serve as free radical scavengers [23]. Grapes have many types and a high content of polyphenolic compound. After being fermented into wine, the polyphenol content is increased, the composition is more stable, and the antioxidant capacity is greatly improved [24-26]. More than 50 polyphenolic compounds in red wine are the most widely used antioxidants. Grape skin 
contains more resveratrol than the grape meat and grape seed [27]. Resveratrol is a polyhydric phenolic compound. In addition to preventing cardiovascular and cerebrovascular diseases, it also has strong anticancer abilities [28]. Some clinical data have shown that procyanidin oligomers from grape seeds are 20 times more potent than vitamin $C$ and 50 times more potent than vitamin E in antioxidants [29]. In addition to their antioxidant activity, grape skin polyphenols also inhibit some enzymes that catalyze the release of histamine, which is responsible for inflammation and allergies [30,31]. In vitro antioxidant studies have also confirmed that KFSE has a strong antioxidant capacity, whether for DPPH or ABTS. The fermentation solution components were separated by HPLC, and the results showed that the fermentation solution included EGCG, coumarin, neochlorogenic acid, rutin, resveratrol, chlorogenic acid, and rosmarinic acid. These ingredients have all been shown to have good antioxidant properties.

Oxidative stress is a negative effect produced by free radicals in the body. It refers to the imbalance of oxidation and antioxidation in the body, which tends to oxidize, leading to inflammatory infiltration of neutrophils, increased secretion of proteases, and the production of a large number of oxidized intermediates. Oxidative stress is considered an important factor leading to ageing and disease.

The superoxide anion reacts with hydrogen ions under the action of SOD to form hydrogen peroxide, which in turn reacts with hydrogen ions under the action of CAT and GSH-Px to finally form harmless substances such as water and oxygen [32]. LDH (lactate dehydrogenase) is a glycolytic enzyme widely distributed in the liver and kidney. An increase in LDH content indicates inflammation [33]. MDA is one of the end products of membrane lipid peroxide and can be used as one of the indicators of oxidative damage model. Depending on the severity of oxidative stress, NO can directly oxidize endogenous antioxidants, destroy non-enzymatic antioxidant defense systems, and inhibit the activity of antioxidant enzymes such as CAT and GSH-Px, leading to an increase in intracellular peroxide content and initiating cellular oxidative damage [34]. At the cellular level, $\mathrm{KFSE}$ can reduce $\mathrm{H}_{2} \mathrm{O}_{2}$-induced oxidative damage in human renal epithelial cells. In our study, we showed that the oxidative markers GSH, GSH-Px, CAT, SOD, and T-AOC were increased, and the content of LDH, MDA, and NO was decreased in cells. In addition, we demonstrated that KFSE was associated with increased oxidative damage in cells with increased expression of intracellular SOD, CAT, GSH-Px, and GSH genes and proteins. GSH as a strong reducing agent that can reduce part of the sulfhydryl form, thereby preventing the thiol from being contained [31]. Proteins and enzymes are protected from peroxide damage.

The genetic information on which organisms depend for survival and reproduction is stored in DNA, so maintaining the integrity of DNA molecules is critical to the survival of cells. The external environment and internal factors of the organism often lead to damage or changes in DNA molecules, which can affect the synthesis of RNA and protein. If the damage to DNA or the change in genetic information cannot be corrected, it may affect the cells. Cellular function or survival may affect germ cells and subsequent offspring.

The $p 53$ gene is closely related to the occurrence, development, and clinical treatment of tumors [35]. It is involved in the regulation of cell cycle, DNA repair, cell differentiation, apoptosis, and other anticancer biological functions [36-38]. The expression product of the $p 21$ gene is the most widely known kinase inhibitor. An active cell cycle inhibitory protein, $p 21$ inhibits the activity of cyclin-D1-CDK4, thereby arresting the cell cycle in G1 phase and inhibiting DNA replication [39]. Moreover, p21 can decrease the expression of PCNA and arrest cells in S phase; CDK4, as a member of the kinase family, is a key regulator of cell transformation from G1 to $S$ phase, and its content and activity level are closely related to the G1/S phase transformation rate of the cell cycle [40]. Elevated expression of CDK4 promotes cell cycle progression and enhances cell proliferation, leading to tumorigenesis. This result was similarly confirmed in the flow cytometry results, and the cell cycle was arrested in the G1/S phase. In our study, the reduction in cell growth and cell cycle arrest by KFSE were accompanied by an increase in apoptotic genes and changes in cell cycle gene expression. In our cell-level studies, it was confirmed that KFSE promoted the expression of $p 53, p 21$, cyclin-D1, CDK4, PCNA, and other genes in cells when to the cells initiated apoptosis. $p 53$ induced upregulation of $p 21$ and other genes, which suggests that this change may play an important role in G1/S phase arrest caused by DNA damage. 
At the protein level, KFSE induced up-regulation of Bax protein expression and decreased NF- $\mathrm{KB}$ protein expression. Bax is one of the most pro-apoptotic proteins in the human body. It can induce the release of Cytc and activate the caspase family of proteases, causing bubble formation, nuclear fragmentation and apoptosis, leading to DNA degradation [41-43]. After acting on HepG2 hepatoma cells, KFSE stimulates the death receptor pathway, and the death receptor is activated by binding to the corresponding ligand. After a series of downstream signal cascades, Caspase8 is activated, and the pro-apoptotic protein Bax is activated.

\section{Conclusions}

In conclusion, grape skin was fermented by Lactobacillus plantarum KFY02, and the variety of polyphenolic compounds increased. KFSE treatment induced cell cycle arrest via the $p 53$ and $p 21$ pathways involved in cell cycle progression and apoptosis, significantly inhibiting the growth of hepatoma cells in vitro. In addition, we demonstrated that the antioxidant capacity of KFSE manifested in vitro and had a beneficial effect on oxidative damage induced by $\mathrm{H}_{2} \mathrm{O}_{2}$ in renal epithelial cells. The Lactobacillus plantarum KFY02 fermented grape skin industry will have potential research value for the development of the future grape supplement industry and the development of functional foods for inhibiting hepatoma.

Author Contributions: J.L. performed the majority of the experiments and wrote the manuscript; X.L. and R.Y. contributed to the data analysis; F.T. and X.Z. designed and supervised the study, and checked the final manuscript.

Funding: This research was funded by Research Project of Chongqing University of Education [KY2015TBZC] and the Program for Innovation Team Building at Institutions of Higher Education in Chongqing (CXTDX201601040), China.

Conflicts of Interest: The authors declare no conflict of interest.

\section{Appendix A}

Table A1. Sequences of primers used in this study.

\begin{tabular}{|c|c|c|}
\hline Gene & Primer Sequence & X (Annealing Temperature $\left({ }^{\circ} \mathrm{C}\right)$ ) \\
\hline \multirow{2}{*}{ GAPDH } & F: 5'-TCAAGAAGGTGGTGAAGCAGG-3' & \\
\hline & R: 5'-AGCGTCAAAGGTGGAGGAGTG-3' & \\
\hline \multirow{2}{*}{$C A T$} & F: 5'-TGGAGCTGGTAACCCAGTAGG-3' & \\
\hline & R: 5'-CCTTTGCCTTGGAGTATTTGGTA-3' & 57.0 \\
\hline \multirow{2}{*}{ SOD1 } & F: 5'-GGTGGGCCAAAGGATGAAGAG-3' & \multirow{2}{*}{57.0} \\
\hline & R: 5'-CCACAAGCCAAACGACTTCC-3' & \\
\hline \multirow{2}{*}{ GSH } & F: 5'-GGGAGCCTCTTGCAGGATAAA-3' & \multirow{2}{*}{57.0} \\
\hline & R: 5'-GAATGGGGCATAGCTCACCAC-3' & \\
\hline \multirow{2}{*}{$G S H-P x$} & F: 5'-CAGTCGGTGTATGCCTTCTCG-3' & \multirow{2}{*}{57.0} \\
\hline & R: 5'-GAGGGACGCCACATTCTCG-3' & \\
\hline \multirow{2}{*}{ p53 } & F: 5'-CTTTGAGGTGCGTGTTTGTGC-3' & \multirow{2}{*}{51.6} \\
\hline & R: 5'-GGTTTCTTCTTTGGCTGGGGA-3' & \\
\hline \multirow{2}{*}{ CDK4 } & F: 5'-ATGGCTACCTCTCGATATGAGC-3' & \multirow{2}{*}{56.6} \\
\hline & R: 5'-CATTGGGGACTCTCACACTCT-3' & \\
\hline \multirow{2}{*}{ Cyclin-D1 } & F: 5'-GCTGCGAAGTGGAAACCATC-3' & \multirow{2}{*}{60.3} \\
\hline & R: 5'-CCTCCTTCTGCACACATTTGAA-3' & \\
\hline \multirow{2}{*}{$p 21$} & F: 5'-TGTCCGTCAGAACCCATGC-3' & \multirow{2}{*}{54.9} \\
\hline & R: 5'-AAAGTCGAAGTTCCATCGCTC-3' & \\
\hline \multirow{2}{*}{$p R b 1$} & F: 5'-CTCTCGTCAGGCTTGAGTTTG-3' & \multirow{2}{*}{66.0} \\
\hline & R: 5'GACATCTCATCTAGGTCAACTGC-3' & \\
\hline \multirow{2}{*}{$C-m y c$} & F: 5'-TGGAACGTCAGAGGAGAAACGA-3' & \multirow{2}{*}{50.0} \\
\hline & R: 5'-CTTGAACGGACAGGATGTAGGC-3' & \\
\hline \multirow{2}{*}{ Caspase-3 } & F: 5'-CATGGAAGCGAATCAATGGACT-3' & \multirow{2}{*}{50.7} \\
\hline & R: 5'-CTGTACCAGACCGAGATGTCA-3' & \\
\hline
\end{tabular}


Table A1. Cont.

\begin{tabular}{|c|c|c|}
\hline \multirow{2}{*}{ Caspase-8 } & F: 5'-ATTTTGAGATCAAGCCCCACG-3' & \multirow{2}{*}{66.0} \\
\hline & R: 5'-GGATACAGCAGATGAAGCAGTCC-3' & \\
\hline Casnase-9 & F: 5'-CTCAGACCAGAGATTCGCAAAC-3' & 500 \\
\hline & R: 5'-GCATTTCСССТCAААСТСТCAA-3' & \\
\hline Caspase-7 & $\begin{array}{l}\text { F: 5'-CGGTCCTCGTTTGTACCGTC-3' } \\
\text { R: 5'-CGCCCATACCTGTCACTTTATCA-3' }\end{array}$ & 64.4 \\
\hline $\cos -2$ & $\begin{array}{l}\text { F: 5'-CTGGCGCTCAGCCATACAG-3' } \\
\text { R: 5'-CGCACTTATACTGGTCAAATCCC-3' }\end{array}$ & 65.0 \\
\hline Bcl-2 & $\begin{array}{l}\text { F: 5'-ATGTGTGTGGAGAGCGTCAACC-3' } \\
\text { R: 5'-CAGAGACAGCCAGGAGAAATCAA-3' }\end{array}$ & 65.0 \\
\hline$N F-\kappa B$ & $\begin{array}{l}\text { F: 5'-GAAGCACGAATGACAGAGGC-3' } \\
\text { R: } 5^{\prime} \text {-GCTTGGCGGATTAGCTCTTTT-3' }\end{array}$ & 50.9 \\
\hline PCNA & $\begin{array}{l}\text { F: 5'-CCAGGGCTCCATCCTCAAGAA-3' } \\
\text { R: } 5^{\prime} \text {-GACGTGGGACGAGTCCATGCT-3' }\end{array}$ & 62.0 \\
\hline$T G F-\beta$ & $\begin{array}{l}\text { F: 5'-CAGCGTGCCTAAACTTTATCAGC-3' } \\
\text { R: 5'-TCAGGAGGATGTTTCACATGGA-3' }\end{array}$ & 58.2 \\
\hline
\end{tabular}

\section{References}

1. Bosch, F.X.; Ribes, J.; Mireia, D.; Ramon, C. Primary liver cancer: Worldwide incidence and trends. Gastroenterology 2004, 127, S5-S16. [CrossRef]

2. Valery, P.C.; Laversanne, M.; Clark, P.J.; Petrick, J.L.; Mcglynn, K.A.; Bray, F. Projections of primary hepatoma to 2030 in 30 countries worldwide. Hepatology 2018, 67, 600-611. [CrossRef]

3. Gay, N.H.; Phopin, K.; Suwanjang, W.; Songtawee, N.; Ruankham, W.; Wongchitrat, P.; Prachayasittikul, S.; Prachayasittikul, V. Neuroprotective effects of phenolic and carboxylic acids on oxidative stress-induced toxicity in human neuroblastoma SH-SY5Y cells. Neurochem. Res. 2018, 43, 1-18. [CrossRef]

4. Zhao, Y.; Zhu, Y.; Wu, L.; Meng, Q.; Liu, M.Z. Effect of resveratrol on proliferation and autophagy of human hepatoma HepG2 cells. Chin. J. Biol. 2018, 31, 607-612.

5. Rush, E.; Ferguson, L.R.; Cumin, M.; Thakur, V.; Karunasinghe, N.; Plank, L. Kiwifruit consumption reduces DNA fragility: A randomized controlled pilot study in volunteers. Nutr. Res. 2006, 26, 197-201. [CrossRef]

6. Giampieri, F.; Gasparrini, M.; Forbes-Hernandez, T.Y.; Mazzoni, L.; Capocasa, F.; Sabbadini, S.; Alvarez-Suarez, J.M.; Afrin, S.; Rosati, C.; Pandolfini, T. Overexpression of the anthocyanidin synthase gene in strawberry enhances antioxidant capacity and cytotoxic effects on human hepatic cancer cells. J. Agric. Food Chem. 2018, 66, 581-592. [CrossRef]

7. Saaara, Y.; Miyata, Y.; Nakamura, Y.; Yasuda, T.; Araki, K.; Matsuo, T.; Ohba, K.; Sakai, H. Anti-cancer effects of green tea consumption on malignant behavior up-regulated by smoking in patients with upper urinary tract cancer. Eur. Urol. Suppl. 2018, 17, e1439. [CrossRef]

8. Kammerer, D.; Claus, A.; Carle, R.; Schieber, A. Polyphenol screening of pomace from red and white grape varieties (Vitis vinifera L.) by HPLC-DAD-MS/MS. J. Agric. Food Chem. 2004, 52, 4360-4367. [CrossRef]

9. Eremina, A.V.; Reshetnyak, V.Y.; Vezirishvili, M.O. HPLC determination of polyphenols in dry grape stem extract. Pharm. Chem. J. 2004, 38, 143-145. [CrossRef]

10. Scalbert, A.; Johnson, I.T.; Saltmarsh, M. Polyphenols: Antioxidants and beyond. Am. J. Clin. Nutr. 2005, 81, 215S-217S. [CrossRef]

11. Kim, S.; Bang, H.; Yoo, K.S.; Pike, L.M. Overexpression of Anthocyanidin Synthase (ANS) gene in strawberry enhances antioxidant capacity and cytotoxic effects on human hepatic cancer cells. J. Agric. Euphytica. 2006, 145, 45-51. [CrossRef]

12. Markowiak, P.; Śliżewska, K. Identification of the fourth allele of the ans (anthocyanidin synthase) gene and its effect on red color intensity in onions (allium cepa). Gut Pathog. 2018, 10, 21-40. [CrossRef]

13. Shori, A.B. Microencapsulation improved probiotics survival during gastric transit. Hayati J. Biosci. 2018, 24, 1-5. [CrossRef]

14. Swati, S.M.; Prafulla, K.B.; Biswabandita, K.; Ramesh, C.R. Advances in probiotics, prebiotics and nutraceuticals. Innov. Technol. Fermented Food Beverage Ind. 2018, 5, 121-141. 
15. George, K.R.; Patra, J.K.; Gouda, S.; Park, Y.; Shin, H.S.; Das, G. Benefaction of probiotics for human health: A review. J. Food Drug Anal. 2018, 26, 927-939. [CrossRef]

16. Azcárate-Peril, M.A.; Sikes, M.; Bruno-Bárcena, J.M. The intestinal microbiota, gastrointestinal environment and colorectal cancer: A putative role for probiotics in prevention of colorectal cancer? Am. J. Physiol. Gastrointest. Liver Physiol. 2011, 301, G401-G424.

17. Bin, X.; Chen, J.; Zhou, Y. Cellular oxidative damage of HEK293T cells induced by combination of $\mathrm{CdCl}_{2}$ and Nano-TiO 2 . J. Huazhong Univ. Sci. Technol. Med. Sci. 2011, 31, 290-294.

18. Thaipong, K.; Boonprakob, U.; Crosby, K.; Cisneros, Z.L.; Byrne, D.H. Comparison of ABTS, DPPH, FRAP, and ORAC assays for estimating antioxidant activity from guava fruit extracts. J. Food Compos. Anal. 2006, 19, 669-675. [CrossRef]

19. Bernini, R.; Barontini, M.; Cis, V.; Carastro, I.; Tofani, D.; Chiodo, R.A.; Lupattelli, P.; Incerpi, S. Synthesis and evaluation of the antioxidant activity of lipophilic phenethyl trifluoroacetate esters by in vitro ABTS, DPPH and in cell-culture DCF assays. Molecules 2018, 23, 208. [CrossRef]

20. Akalin, A.; Elmore, L.W.; Forsythe, H.L.; Amaker, B.A.; Holt, S.E. A novel mechanism for chaperone-mediated telomerase regulation during prostate cancer progression. Cancer Res. 2001, 61, 4791-4796.

21. Juan, M.E.; Wenzel, U.; Daniel, H.; Planas, J.M. Resveratrol induces apoptosis through ROS-dependent mitochondria pathway in HT-29 human colorectal carcinoma cells. J. Agric. Food Chem. 2008, 56, 4813-4818. [CrossRef] [PubMed]

22. Suh, D.K.; Lee, E.J.; Kim, H.C.; Kim, J.H. Induction of G(1)/S phase arrest and apoptosis by quercetin in human osteosarcoma cells. Arch. Pharm. Res. 2010, 33, 781-785. [CrossRef] [PubMed]

23. Arora, P.; Ansari, S.H.; Nazish, I. Bio-functional aspects of grape seeds-A review. Int. J. Phytomed. 2011, 2, 177-181.

24. Nardini, M.; Garaguso, I. Effect of sulfites on antioxidant activity, total polyphenols, and flavonoid measurements in white wine. Foods 2018, 7, 35. [CrossRef] [PubMed]

25. Aoyama, H.; Sakagami, H.; Hatano, T. Three new flavonoids, proanthocyanidin, and accompanying phenolic constituents from Feijoa sellowiana. Biosci. Biotech. Biochem. 2018, 82, 1-11.

26. Lili, X.U.; Yue, Q.Y.; Bian, F.E.; Zhai, H.; Yao, Y.X. Melatonin Treatment enhances the polyphenol content and antioxidant capacity of red wine. Hortic. Plant J. 2018, 4, 144-150.

27. Tzanova, M.; Peeva, P. Rapid HPLC method for simultaneous quantification of trans-resveratrol and quercetin in the skin of red grapes. Food Anal. Methods 2018, 11, 514-521. [CrossRef]

28. Xue, B.; Lu, Q.Y.; Massie, L.; Qualls, C.; Mao, J.T. Grape seed procyanidin extract against lung cancer: The role of microrna-106b, bioavailability, and bioactivity. Oncotarget 2018, 9, 15579-15590. [CrossRef]

29. Eng, E.T.; Ye, J.D.; Phung, S.; Moore, R.E.; Young, M.K.; Gruntmanis, U.; Braunstein, G.; Chen, S. Suppression of estrogen biosynthesis by procyanidin dimers in red wine and grape seeds. Cancer Res. 2003, 63, 8516-8522.

30. Shaik, Y.B.; Castellani, M.L.; Perrella, A.; Conti, F.; Cerulli, G. Role of quercetin (a natural herbal compound) in allergy and inflammation. J. Biol. Reg. Homeos. Agents 2006, 20, 47-52.

31. Shelly, H.; Corene, C.; Sun, S.; Sun, X.X.; Hoda, K.; Zhou, K.Q. Dietary supplementation of grape skin extract improves glycemia and inflammation in diet-induced obese mice fed a western high fat diet. J. Agric. Food Chem. 2011, 59, 3035-3041.

32. Haddad, J.J.; Harb, H.L. L-gamma-Glutamyl-L-cysteinyl-glycine (glutathione; GSH) and GSH-related enzymes in the regulation of pro- and anti-inflammatory cytokines: A signaling transcriptional scenario for redox(y) immunologic sensor(s)? Mol. Immunol. 2005, 42, 987-1014. [CrossRef] [PubMed]

33. Zelko, I.N.; Mariani, T.J.; Folz, R.J. Superoxide dismutase multigene family: A comparison of the CuZn-SOD (SOD1), Mn-SOD (SOD2), and EC-SOD (SOD3) gene structures, evolution, and expression. Free Radic. Biol. Med. 2002, 33, 337-349. [CrossRef]

34. Chu, H.; Low, P.S. Mapping of glycolytic enzyme-binding sites on human erythrocyte band 3. Biochem. J. 2006, 400, 143-151. [CrossRef] [PubMed]

35. Long, X.Y.; Pan, Y.N.; Zhao, X. Prophylactic effect of Kudingcha polyphenols on oxazolone induced colitis through its antioxidant capacities. Food Sci. Hum. Wellness 2018, 7, 209-214. [CrossRef]

36. Kim, M.P.; Lozano, G. Mutant p53 partners in crime. Cell Death Differ. 2018, 25, 161-168. [CrossRef] [PubMed]

37. Marcus, J.M.; Burke, R.T.; Doak, A.E.; Soyeon, P.; Orth, J.D. Loss of p53 expression in cancer cells alters cell cycle response after inhibition of exportin-1 but does not prevent cell death. Cell Cycle 2018, 17, 1-16. [CrossRef] 
38. Collins, A.R.; Ma, A.G.; Duthie, S.J. Implication of p53 in base excision DNA repair: In vivo evidence. Oncogene 2002, 21, 731-737.

39. Wang, W.; Zeng, C.; Feng, Y.; Zhou, F.; Liao, F.; Liu, Y. The size-dependent effects of silica nanoparticles on endothelial cell apoptosis through activating the p53-caspase pathway. Environ. Pollut. 2018, 233, 218-225. [CrossRef]

40. Zeng, L.; Xiao, Q.; Margariti, A.; Xu, Q. Shear stress-induced stem cell differentiation toward endothelial cells is regulated by HDAC-P53-P21 pathways. Vasc. Pharm. 2006, 45, e52. [CrossRef]

41. Meyer, C.A.; Jacobs, H.W.; Datar, S.A.; Du, W.; Lehner, C.F. Drosophila Cdk4 is required for normal growth and is dispensable for cell cycle progression. Embo J. 2014, 19, 4533-4542. [CrossRef] [PubMed]

42. Haddadi, R.; Nayebi, A.M.; Eyvari, S.B. Silymarin prevents apoptosis through inhibiting the Bax/caspase-3 expression and suppresses toll like receptor-4 pathway in the SNc of 6-OHDA intoxicated rats. Biomed. Pharm. 2018, 104, 127-136. [CrossRef] [PubMed]

43. Ballestri, S.; Nascimbeni, F.; Romagnoli, D.; Baldelli, E.; Lonardo, A. The role of nuclear receptors in the pathophysiology, natural course, and drug treatment of NAFLD in humans. Adv. Ther. 2016, 33, 291-319. [CrossRef] [PubMed]

(C) 2019 by the authors. Licensee MDPI, Basel, Switzerland. This article is an open access article distributed under the terms and conditions of the Creative Commons Attribution (CC BY) license (http://creativecommons.org/licenses/by/4.0/). 